\title{
MISCANTUS PRODUCTIVITY \\ IN VARIOUS FERTILIZATION RATES
}

\section{Mykola Radchenko ${ }^{1}$ Anna Bazalii ${ }^{2}$}

\section{DOI: https://doi.org/10.30525/978-9934-588-39-6-33}

Among the many herbaceous plants cereals take significant place in terms of their worldwide distribution, importance and diverse use. Representatives of the miscanthus genus are among the most productive cereals that have received wide recognition in the last decade. First of all, this is a natural hybrid - a miscanthus giant. Plants of this genus are well known as fodder, ornamental, technical, cellulose, phytomeliorative etc. In the recent period, the focus of both the scientific community and producers has been drawn to the use of miscanthus as an energy plant as a source for the production of various types of biofuels [1, p. 50].

The problem of the use of alternative sources of energy from renewable raw materials is becoming more urgent for today's society in the connection with the energy crisis and the deteriorating environmental condition [2, p. 152].

Until the beginning of the fifth century, miscanthus was only used in China as an anti-erosion plant. Most likely he came to Europe in the XVI century, but it was used only as a finishing plant. In 1935, Danish scientist Ansel Olsen brought to Europe a Japanese clone, which became the basis for the selection of plants used until now. Due to the great harvest, Karl Foster named this plant Miscanthus sinensis «Giganteus». From a scientific point of view, this plant was studied for the first time in 1983 at the Plant Breeding Station in Denmark. Since then, intensive research has been carried out on this culture in many European countries, namely Germany, the United Kingdom, Italy, France, Spain, Poland [3, p. 86].

The widespread introduction of miscanthus into the crop culture will contribute not only to the production of renewable energy from biomass, but also to the improvement of the ecological status of Ukraine's agricultural landscapes [4, p. 6].

When growing phyto-energy crops, an important element of technology is the use of fertilizers to increase the yield of vegetative mass. Therefore, it is necessary to investigate the growth, development and productivity of miscanthus plants, depending on the nutritional background. One of the important conditions for

\footnotetext{
${ }^{1}$ Sumy National Agrarian University, Ukraine

${ }^{2}$ Sumy National Agrarian University, Ukraine
} 
obtaining high miscanthus yields at rational costs for its cultivation is to determine optimal fertilizer rates. According to Professor V. Zinchenko, with a yield of 20 tonnes of dry miscanthus weight per 1 ha, about $60 \mathrm{~kg}$ of N, $16 \mathrm{~kg}$ of P2O5, $80 \mathrm{~kg}$ of $\mathrm{K} 2 \mathrm{O}$ are harvested at low fertilizer levels. Application of nitrogen fertilizers up to $90 \mathrm{~kg}$ / ha has a very positive effect on the production of biomass. Common nutrient requirements are as follows: nitrogen $(\mathrm{N})$ 2-5, phosphorus $(\mathrm{P})$ $0.3-1.1 \mathrm{~kg} / \mathrm{t}$ of dry weight [5, p. 131].

A promising area of researches is further study as for establishing the economic feasibility and payback of different doses of fertilizers, as well as exploring new technology elements for growing miscanthus.

The purpose of the research was to study the productivity of miscanthus at different doses of fertilizers as a promising energy crop for biofuels production in the northeastern part of the Forest-Steppe of Ukraine.

The researches were carried out on the basis of the educational and scientific production center of Sumy National Agrarian University according to the conventional methods [6] during 2018-2019. Soils of the experimental field of chernozem are typical powerful heavy-loamy medium humus, characterized by the following indicators: humus content in the arable layer (according to I.V. Tiuryn) $-4.0 \%$, the reaction of soil solution is close to neutral ( $\mathrm{pH}$ 6.5), the content of easily hydrolyzed nitrogen (according to I.V. Tiuryn) $9.0 \mathrm{mg}$, mobile phosphorus and metabolic potassium (according to F. Chyrikov) respectively14 $\mathrm{mg}$ and $6.7 \mathrm{mg}$ per 100 soil.

Agrotechnics in the experiment corresponded to the recommended at the time of their conduct for the area of the northeastern part of the Forest-Steppe of Ukraine, except for the agro-measure which was provided by the scheme of the experiment for the study, namely the dose of mineral fertilizers. Among nitrogen fertilizers we used ammonium nitrate.

The field experiments were laid out in a randomized manner in triplicate. The accounting area of the elementary plot was $50 \mathrm{~m}^{2}$. Miscanthus Osinnii Zoretsvit was used as the study material.

Scheme of experience:

- control (without fertilizers);

$-\mathrm{N}_{30}$ - application in the tillering phase;

- $\mathrm{N}_{60}$ - application in the tillering phase;

The growth and development rates of miscanthus plants during the growing season make it possible to influence well-timed the process of formation of high crop productivity.

Formation of overground mass of miscanthus, height in particular, depends on the morphological features of the variety, hydrothermal and agrotechnological measures, including fertilizer. Thus, in the fertilizer-free version, the height of the main shoot was the lowest during the whole growing 
season. In the second decade of July the height of the plants under control was $172.4 \mathrm{~cm}$, while in the fertilized variants it was higher by $14.0-39.2 \mathrm{~cm}$. In August, the height of the main shoot of miscanthus was on average 29-31 cm higher than in July. In August, the height of the main shoot ranged from 201.3 to $241.8 \mathrm{~cm}$, depending on the variants studied. The maximum height of $241.8 \mathrm{~cm}$ was observed in the fertilizer variant $\mathrm{N}_{60}$, and the lowest $201.3 \mathrm{~cm}$ was observed in the fertilizer-free version.

In the summer, from the end of July, the lower leaves grow old, because the developed leaf potential of the crop prevents sufficient plant light. In the autumn after the first frost, aging accelerates and nutrients accumulate in the rhizomes. The leaves die off, and subsequently the stems dry out during the winter to relatively low moisture content. Accordingly the weight of the plant decreases.

At the end of the growing season (late August to early September) the weight of the plants ranged from 48.5 to $77.0 \mathrm{~g}$. in the version $\mathrm{N}_{60}$. The lowest weight of the plants was observed in the control $-48.5 \mathrm{~g}$, which is more by $20.5 \mathrm{~g}$ in variant $\mathrm{N}_{30}$ and $28.5 \mathrm{~g}$ in variant $\mathrm{N}_{60}$. Thus, the maximum weight was $77.0 \mathrm{~g}$ in variant $\mathrm{N}_{60}$.

The weight of the dry plant in the control was $25.1 \mathrm{~g}, \mathrm{~N}_{30}-32.5 \mathrm{~g}, \mathrm{~N}_{60}-$ $37.1 \mathrm{~g}$. The maximum weight of the dry plant was noted in variant $\mathrm{N}_{60}-$ $37.1 \mathrm{~g}$, which is more than $4.6 \mathrm{~g}$ in variant $\mathrm{N}_{30}$ and $12 \mathrm{~g}$ in the control.

An important indicator that determines the size of the assimilation surface per unit area is the density of the stem, which, unlike the density of standing plants depends on the features of their development, in particular the ability to form additional shoots in specific conditions.

The sampling density of miscanthus plants with application of different fertilizer doses varied. Thus, the highest density was observed in variant $\mathrm{N}_{60}$ and was 42 pieces per $\mathrm{m}^{2}$; slightly lower density was obtained in variant $\mathrm{N}_{30}-38$ pieces per $\mathrm{m}^{2}$ and the lowest density was formed at the control of 37.0 pieces per $\mathrm{m}^{2}$.

The main indicator of the miscanthus giant in terms of economic value as biomass is yield. The yield of miscanthus plants increased with the introduction of mineral fertilizers (Figure 1).

Analyzing the miscanthus giant yield over the years of research and according to variants, it was noted that the maximum yield by fertilizer doses was obtained on variant $\mathrm{N}_{60}-15.58 \mathrm{t} / \mathrm{ha}$, which is more by $20.7 \%$ for variant $\mathrm{N}_{30}(12.35 \mathrm{t} / \mathrm{ha})$ and $40.4 \%$ for control (9.29 t/ha).

According to the results of the research, it was found that the best conditions for the growth, development and formation of the crop formed on the variant with the application of mineral fertilizers at a dose of $\mathrm{N}_{60}$. The application of mineral fertilizers at the dose of $\mathrm{N}_{60}$ ensured a maximum height of $241.8 \mathrm{~cm}$, the weight of the dry plant was $37.1 \mathrm{~g}$, with a pre-harvesting density of 42.0 pieces per $\mathrm{m}^{2}$ and yield of $15.58 \mathrm{t} / \mathrm{ha}$. 


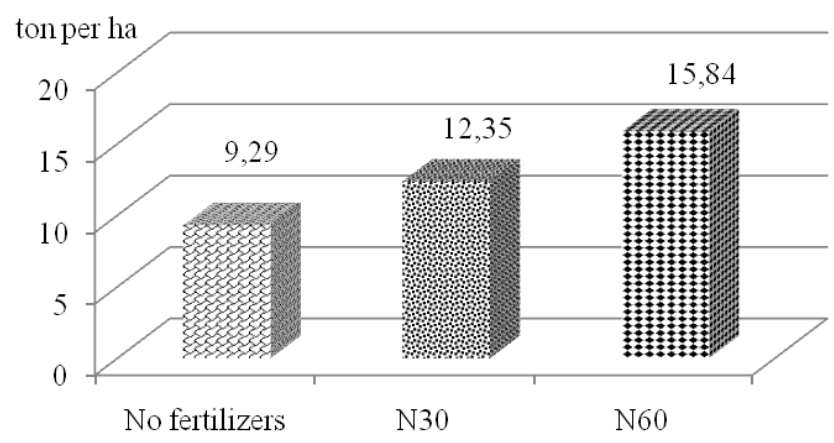

Figure 1. The yield of dry biomass of miscanthus plants depending on the dose of mineral fertilizers (average for 2018-2019), $t$ / ha

\section{References:}

1. Fedorchuk, M. I. (2017). Agrotekhnolohichni aspekty vyroschuvannia enerhetychnykh kultur $v$ umovakh pivdnia Ukrainy [Agrotechnological aspects of energy-yielding crops growing under the conditions of the south of Ukraine]. Kherson: DVNZ «Khersonskyi derzhavnyi ahrarnyi universytet». (in Ukrainian)

2. Rakhmetov, D. B. (2011). Teoretychni ta prykladni aspekty introduktsii roslyn v Ukraini [Theoretical and applied aspects of plants introduction in Ukraine]. Kyiv: AhrarMediaHrup. (in Ukrainian)

3. Dubrovin, V. O. (2014). Perspektyvy rozvytku alternatyvnoi enerhetyky na Polissi Ukrainy [Future directions of alternative energetics development in the forest area of Ukraine]. Kyiv: Tsentr uchbovoi literatury. (in Ukrainian)

4. Roik, M. V., Kurylo, V. L., Hanzhenko, O. M., \& Humentyk, M. Ya. (2012). Perspektyvy rozvytku bioenerhetyky $\mathrm{v}$ Ukraini [Future directions of bioenergetics development in Ukraine]. Tsukrovi buriaky - Sugar beet, no. 2-3, pp. 6-8. (in Ukrainian)

5. Zinchenko, V. O., \& Kusailo, V. P. (2006). Biohelioenerhiia - nashe enerhetychne maibutnie [Biosolarenergy is our energetic future]. Propozytsiia Proposition, no. 8, pp. 130-132. (in Ukrainian)

6. Dospekhov, B. A. (1985). Metodika polevogo opyta [Methodology of field experiment]. Moskva: Agropromizdat. (in Russian) 